\title{
Impacts of extreme precipitation and seasonal changes in precipitation on plants
}

\author{
M. J. B. Zeppel ${ }^{1}$, J. V. Wilks ${ }^{1}$, and J. D. Lewis ${ }^{2,3}$ \\ ${ }^{1}$ Department of Biological Sciences, Macquarie University, NSW 2109, Australia \\ ${ }^{2}$ Hawkesbury Institute for the Environment, University of Western Sydney, Richmond, NSW 2753, Australia \\ ${ }^{3}$ Louis Calder Center - Biological Field Station and Department of Biological Sciences, Fordham University, \\ Armonk, NY 10504, USA
}

Correspondence to: M. J. B. Zeppel (melanie.zeppel@mq.edu.au)

Received: 11 September 2013 - Published in Biogeosciences Discuss.: 28 October 2013

Revised: 21 March 2014 - Accepted: 26 March 2014 - Published: 13 June 2014

\begin{abstract}
The global hydrological cycle is predicted to become more intense in future climates, with both larger precipitation events and longer times between events in some regions. Redistribution of precipitation may occur both within and across seasons, and the resulting wide fluctuations in soil water content (SWC) may dramatically affect plants. Though these responses remain poorly understood, recent research in this emerging field suggests the effects of redistributed precipitation may differ from predictions based on previous drought studies. We review available studies on both $e x$ treme precipitation (redistribution within seasons) and seasonal changes in precipitation (redistribution across seasons) on grasslands and forests.

Extreme precipitation differentially affected above-ground net primary productivity (ANPP), depending on whether extreme precipitation led to increased or decreased SWC, which differed based on the current precipitation and aridity index of the site. Specifically, studies to date reported that extreme precipitation decreased ANPP in mesic sites, but, conversely, increased ANPP in xeric sites, suggesting that plant-available water is a key factor driving responses to extreme precipitation. Similarly, the effects of seasonal changes in precipitation on ANPP, phenology, and leaf and fruit development varied with the effect on SWC. Reductions in spring or summer generally had negative effects on plants, associated with reduced SWC, while subsequent reductions in autumn or winter had little effect on SWC or plants. Similarly, increased summer precipitation had a more dramatic impact on plants than winter increases in precipitation.
\end{abstract}

The patterns of response suggest xeric biomes may respond positively to extreme precipitation, while comparatively mesic biomes may be more likely to be negatively affected. Moreover, seasonal changes in precipitation during warm or dry seasons may have larger effects than changes during cool or wet seasons. Accordingly, responses to redistributed precipitation will involve a complex interplay between plant-available water, plant functional type and resultant influences on plant phenology, growth and water relations. These results highlight the need for experiments across a range of soil types and plant functional types, critical for predicting future vegetation responses to future climates.

\section{Introduction}

Two critical priorities under future climates are managing water resources and understanding the impacts of climate change on vegetation. Climate change may dramatically alter water resources through changes in the timing of precipitation in many regions (Christensen et al., 2007; IPCC, 2011; Smith, 2011). Increasing evidence suggests that variability and extremes in precipitation are more important drivers of ecosystem processes than mean conditions (Heisler-White et al., 2008; Heisler-White et al., 2009; Smith, 2011; Reyer et al., 2012; Thompson et al., 2013). In particular, both the size and timing of rain events are strong drivers of ecological processes (Schwinning and Sala, 2004; Zeppel et al., 2008a). As a result, responses to changes in the distribution of precipitation over time are likely to differ from responses to individual 
drought events (Luo et al., 2011). While the effects of individual droughts have been extensively studied (Breshears et al., 2009; Allen et al., 2010), the effects of altered timing of precipitation on plants remain largely unknown (Misson et al., 2011; Volder et al., 2013).

In addition to direct effects on plant growth and mortality rates, altered timing of precipitation may have significant effects on local climatic conditions. This is because local ecosystems such as forests can have a strong influence on temperature, precipitation and albedo (Bonan, 2008). For example, reductions in plant growth and increases in mortality often affect complex links among soil biochemistry, land-surface interactions, and carbon and water fluxes, which may alter stream flow and increase evapotranspiration (Keith et al., 2009; Adams et al., 2011). This creates land-surface feedbacks between vegetation, hydrology and climates (Adams et al., 2011).

To address these issues, we need an understanding of the influence of redistributed timing of precipitation on processes across a range of plant functional types, such as shallow- and deep-rooted plants (Fay et al., 2008; Beier et al., 2012). Previous reviews have highlighted the striking gap in understanding how plants respond to extreme and altered seasonality of precipitation (Beier et al., 2012; Reyer et al., 2012). Here, we describe the experimental and modelled results of plant responses to altered seasonality of precipitation and extreme precipitation, addressing a key research gap. While a combination of manipulative studies and observational studies, such as those by Zhang et al. (2013) which describe variation in precipitation, will be required to fully understand the effects of extreme precipitation, here we specifically focus on manipulative experiments and modelling of responses to extreme precipitation.

Our primary objective is to review the current knowledge of the effects of altered timing of precipitation on grassland and forest ecosystems, ranging from semi-arid grasslands and savannas and Mediterranean and temperate forests to tundra and boreal ecosystems. We examine effects of redistributed precipitation on plant processes, including stomatal conductance, leaf water potential, and above ground primary productivity (ANPP) and soil fluxes. Finally, we assess (1) how plants respond to changed seasonality of precipitation, (2) under what circumstances extreme precipitation leads to increased ANPP, and when it leads to lower ANPP, and (3) whether plants in those circumstances are water-limited to begin with.

Here, we use the following terms (Fig. 1): "altered" or "redistributed" precipitation includes both "seasonal redistribution" and "extreme precipitation". "Extreme" means both the amount of and the time between rain events are increased, while the total quantity of precipitation remains constant (see Smith, 2011). "Seasonal redistribution" means reduced precipitation for an entire month or season, with increased precipitation in a later month or season (see Volder et al., 2013).

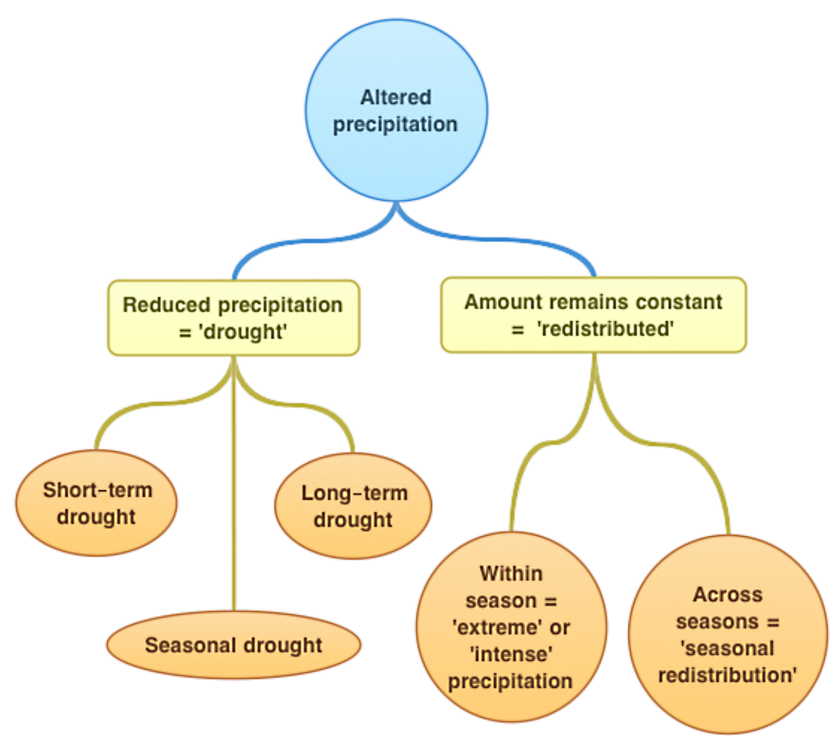

Figure 1. A schematic diagram explaining different types of altered precipitation. If the amount of precipitation is substantially reduced, this may be defined as "drought". Descriptions of drought should include duration (e.g. short-term, long-term and seasonal drought) and also intensity (slight, moderate or severe), which will depend upon site conditions and species. If the amount of precipitation is not reduced, then this may be defined as "redistributed" precipitation, where the total amount of water remains constant but the amount of water and timing between watering events increase. Redistributed precipitation may take place within a season, for example, a rainout shelter within a growing season (Fay et al., 2008), or within glasshouses over a three-month period. Redistributed precipitation may also take place across seasons, where water is withheld during one season and supplementally reapplied in the following months/seasons. For further explanation of "extreme" precipitation events, see Smith (2011).

\subsection{Past and projected changes in the timing of precipitation}

The hydrological cycle has been intensifying over the past century (Huntington, 2006) and is projected to continue to intensify with both the size of and time between rain events increasing (Christensen et al., 2007; IPCC, 2011). Specifically, climate change is predicted to alter the timing, from one season or period to another, and event size of precipitation, resulting in fewer, large rather than many smaller rain events (Pitman and Perkins, 2008; CSIRO, 2011; IPCC, 2011). Further, changes in the seasonality of precipitation are expected to exhibit substantial regional and temporal variation (Christensen et al., 2007).

Projections for future climate scenarios are that many regions will experience more intense, extreme precipitation (Christensen et al., 2007; Smith, 2011), whereas some regions are projected to receive seasonal shifts, including Africa (Hely et al., 2006), oak savannas (Volder et al., 2013) and prairies in the United States (Chimner et al., 2010), 
southern Australia (CSIRO, 2011) and Mediterranean regions (Misson et al., 2011), including semi-arid Spain (Miranda et al., 2009a). Southern France and south-east Australia may experience decreased precipitation in spring and increases in autumn (CSIRO, 2011; Misson et al., 2011). Mixed-grass prairies in the United States are projected to receive wetter winters and drier summers (Chimner et al., 2010), whereas oak savannas are projected to experience drier summers and wetter spring and autumn (Volder et al., 2013). Semi-arid Spain is projected to receive wetter winters, and drier spring and autumn periods (Miranda et al., 2009a), leading to potential changes in soil and plant processes.

The most direct result of redistributed precipitation is altered soil water content (SWC), with less plant-available water in some periods and more in other periods, though specific patterns will depend upon differences in soil characteristics. Increased pulses of rain have strong impacts on plants in water-limited regions (Zeppel et al., 2008a; Resco et al., 2009), and may increase deep drainage in waterabundant regions. These changes in SWC are likely to be exacerbated by predicted rising temperatures, intensified heat waves (Smith, 2011), increasing evaporation and transpiration. Therefore, plant responses to future climates are likely to reflect much larger fluctuations in SWC than historically experienced (Knapp et al., 2002; Weltzin et al., 2003), highlighting the urgent need to understand plant responses to extreme and seasonal changes in rainfall events (Smith, 2011).

\subsection{How might plants respond?}

Variation in SWC and soil characteristics often have a substantial effect on plant and soil processes (Fig. 2) (Brzostek et al., 2012). Increasingly large fluctuations in SWC following redistributed precipitation also drive physiological responses, community structure and the distribution of plant functional types (Volder et al., 2013). Extreme precipitation may influence plant water relations, hydraulic architecture and ANPP (Reyer et al., 2012), whereas changing seasonal precipitation may also influence phenology, including fruit, leaf and early/late wood development, as well as tiller development of grasses (Volder et al., 2010; Misson et al., 2011).

There is a hierarchy of ecological responses to rain events, ranging from hours to decades (Schwinning and Sala, 2004). When changes in precipitation are comparatively small, plants show a limited response (Gerten et al., 2008; Miranda et al., 2009a). However, under future climates, the variability in SWC that plants experience is likely to rapidly increase beyond current limits (Smith, 2011). The current framework on the effects of altered timing of precipitation suggests that extreme precipitation would lead to increased run-off and deep drainage, shallow soil becoming drier, and reduced plant growth when water is already limiting or the soil waterlogged (Knapp et al., 2008). We test this framework against experimental and modelled data.

\subsection{Factors regulating the effects of redistributed precipitation}

The influence that redistributed precipitation will have on plant processes is likely to depend upon soil properties, microclimate, plant functional type and the nature of the change in timing. Soil water content is driven in part by soil type, texture, soil depth and density. Microclimatic factors that influence evapotranspiration also determine whether changes in timing have a large impact (Fay et al., 2008; Zeppel et al., 2008b). Further, current mean annual precipitation (MAP), which influences whether the site is xeric, mesic or hydric, will be a key factor in determining whether plant growth increases or declines (Knapp et al., 2008; Heisler-White et al., 2009). Added effects of heat stress, rising mean temperatures, elevated $\mathrm{CO}_{2}$, vapour pressure deficit $(D)$ and the current season when most precipitation falls, which influence snowfall and snowmelt, are also likely to influence plant responses to altered precipitation (Volder et al., 2010).

Plant functional type could also affect the response to changes in timing. Shallow-rooted versus deep-rooted plants, deciduous versus evergreen plants, and seedlings and mature trees versus midlife trees may exhibit contrasting responses to altered precipitation (Knapp et al., 2008; Zeppel et al., 2011). More broadly, responses of ANPP to precipitation are likely to vary among biomes (Huxman et al., 2004).

This paper discusses extreme precipitation, defined as when the volume remains constant, while the timing of precipitation shifts, within a season or across seasons. However, we note that the impact of repeated extreme precipitation events, such as one severe drought followed by another severe drought, even years apart, is also likely to have a more negative effect on plant mortality compared with altered precipitation within only one year (Anderegg et al., 2013). The impact of repeated water stress on plants has been reported to lead to plant senescence, leaf mortality (Dreesen et al., 2014) and accumulated xylem damage in a process known as cavitation fatigue, where successive exposure to water limitation increases the risk of plant mortality (Anderegg et al., 2013). In order to identify which variables mediate responses to extreme precipitation, and to what extent, we now discuss the results of precipitation timing experiments.

\subsection{Results of precipitation timing experiments}

Many field experiments have imposed drought (Hanson et al., 2003; Wullschleger and Hanson, 2006; Beier et al., 2012) or described the impact of pulses of precipitation (Fravolini et al., 2005; Potts et al., 2006; Zeppel et al., 2008a; Resco et al., 2009). Here, we focus on seasonal changes in precipitation and extreme precipitation. Altered seasonality of precipitation may be implemented, for example, by delivering $80 \%$ of annual precipitation in spring or winter, while retaining the same annual volume (Bates et al., 2006) (Table 1). Alternatively, extreme precipitation regimes have been imposed 
Table 1. Responses of vegetation to changed seasonal precipitation. Biome, site location, latitude and longitude, experimental reduction in precipitation, mean annual precipitation (MAP), and description of whether experimental reduction in precipitation $(P)$ was reduced or redistributed, in addition to the measured response and source reference. Results represent a selection of studies and are not a comprehensive list. Abbreviations: ANPP = above-ground net primary productivity; $A_{n}=$ photosynthesis; $\psi_{\mathrm{m}}=$ midday leaf water potential $(\mathrm{kPa})$; $\psi_{\text {pd }}=$ predawn leaf water potential; $g_{\mathrm{s}}=$ stomatal conductance.

\begin{tabular}{|c|c|c|c|c|c|c|c|c|}
\hline Biome & Site & $\begin{array}{l}\text { Latitude \& longi- } \\
\text { tude }\end{array}$ & $\%$ reduction in precip & $\begin{array}{l}\text { MAP } \\
(\mathrm{mm})\end{array}$ & $\begin{array}{l}\text { Seasonal } \\
\text { /annual re- } \\
\text { duction }\end{array}$ & $\begin{array}{l}P \text { reduced or } \\
\text { redistributed }\end{array}$ & Growth response & Reference \\
\hline Grassland & SE Spain & $\begin{array}{l}36^{\circ} 49^{\prime} \mathrm{N} \\
2^{\circ} 15^{\prime} \mathrm{W}\end{array}$ & $\begin{array}{l}75 \%, 50 \% \text { and altered } \\
\text { timing }\end{array}$ & 200 & $\begin{array}{l}\text { Seasonal } \\
\text { and annual }\end{array}$ & $\begin{array}{l}\text { Reduced and } \\
\text { distributed }\end{array}$ & $\begin{array}{l}\text { Accentuated seasonality reduced biomass } \\
\text { and recruitment }\end{array}$ & Miranda et al. (2009b) \\
\hline Cold desert Grasslands & $\begin{array}{l}\text { Canyonlands } \\
\text { National } \\
\text { Park, Utah, }\end{array}$ & $\begin{array}{l}38.1755^{\circ} \mathrm{N} \\
109.7202^{\circ} \mathrm{W}\end{array}$ & $\begin{array}{l}\text { Winter, summer or year- } \\
\text { long drought. }\end{array}$ & 215 & $\begin{array}{l}\text { Winter and } \\
\text { summer }\end{array}$ & $\begin{array}{l}\text { Annual } \\
\text { reduced }\end{array}$ & $\begin{array}{l}\text { Summer drought effects on } \psi_{\mathrm{pd}} \text { higher } \\
\text { than the winter drought effects; } g_{\mathrm{s}} \text { re- } \\
\text { duced }\end{array}$ & $\begin{array}{l}\text { Schwinning } \\
\text { et al. (2005a) }\end{array}$ \\
\hline Grassland & $\begin{array}{l}\text { Great Basin, } \\
\text { Oregon, USA }\end{array}$ & $\begin{array}{l}119^{\circ} 43^{\prime} \mathrm{W} \\
43^{\circ} 29^{\prime} \mathrm{N}\end{array}$ & $\begin{array}{l}\text { 1) } 80 \% \text { falls in winter; } \\
\text { 2) } 80 \% \text { in spring }\end{array}$ & 300 & $\begin{array}{l}\text { Winter and } \\
\text { spring }\end{array}$ & Redistributed & $\begin{array}{l}\text { Winter comparable to control } \\
\text { Spring treatment, less biomass }\end{array}$ & Bates et al. (2006) \\
\hline Shrub steppe & $\begin{array}{l}\text { Great Basin, } \\
\text { Oregon, USA }\end{array}$ & $\begin{array}{l}119^{\circ} 43^{\prime} \mathrm{W} \\
43^{\circ} 29^{\prime} \mathrm{N}\end{array}$ & $\begin{array}{l}\text { "winter", "spring" or } \\
\text { "current" }\end{array}$ & 300 & $\begin{array}{l}\text { Winter and } \\
\text { spring }\end{array}$ & Redistributed & Shifts to spring reduced growth & Svejcar et al. (2003) \\
\hline Arctic tundra & $\begin{array}{l}\text { Brooks } \\
\text { Range, } \\
\text { Alaska. }\end{array}$ & $\begin{array}{l}149^{\circ} 38^{\prime} \mathrm{W} \\
68^{\circ} 38^{\prime} \mathrm{N}\end{array}$ & Increased w snow fence. & 318 & Winter & Increased & $\begin{array}{l}\text { Deeper snow altered amount and timing } \\
\text { of plant-available } \mathrm{N}\end{array}$ & Schimel et al. (2004) \\
\hline Mixed-grass prairie & $\begin{array}{l}\text { Wyoming, } \\
\text { USA }\end{array}$ & $\mathrm{n} / \mathrm{a}$ & $\begin{array}{l}\text { 1) }+50 \% \text { winter } \\
\text { 2) }+50 \% \text { summer } \\
\text { 3) }-50 \% \text { summer }\end{array}$ & 380 & $\begin{array}{l}\text { Winter and } \\
\text { summer }\end{array}$ & $\begin{array}{l}\text { Increased and } \\
\text { decreased }\end{array}$ & $\begin{array}{l}\text { 1) } 50 \% \text { biomass increase } \\
\text { 2) } 44 \% \text { increase } \\
\text { 3) } 18 \% \text { decrease }\end{array}$ & Chimner et al. (2010) \\
\hline Temperate, savanna & $\begin{array}{l}\text { South-east } \\
\text { Arizona, } \\
\text { USA }\end{array}$ & $\begin{array}{l}31^{\circ} 29^{\prime} \mathrm{N} \\
110^{\circ} 20^{\prime} \mathrm{W}\end{array}$ & $\begin{array}{l} \pm 50 \% \text { in summer and } \\
\text { winter. }\end{array}$ & 602 & $\begin{array}{l}\text { Winter and } \\
\text { summer }\end{array}$ & $\begin{array}{l}\text { Reduced and } \\
\text { redistributed }\end{array}$ & $\begin{array}{l}\text { Summer precipitation more important for } \\
\text { seeding growth }\end{array}$ & $\begin{array}{l}\text { Weltzin and } \\
\text { McPherson (2000) }\end{array}$ \\
\hline Mediterranean forest. & $\begin{array}{l}\text { Montpelier, } \\
\text { Southern } \\
\text { France }\end{array}$ & $\begin{array}{l}3^{\circ} 35^{\prime} 45^{\prime \prime} \mathrm{E} \\
43^{\circ} 44^{\prime} 29^{\prime \prime} \mathrm{N}\end{array}$ & $\begin{array}{l}-97 \% \text { autumn, } \\
-87 \% \text { spring }\end{array}$ & 1127 & $\begin{array}{l}\text { Spring and } \\
\text { autumn }\end{array}$ & $\begin{array}{l}\text { Seasonal re- } \\
\text { ductions }\end{array}$ & $\begin{array}{l}\text { Autumn - no effect, } \\
\text { Spring - more negative } \psi_{\mathrm{m}}\end{array}$ & Misson et al. (2011) \\
\hline Boreal, spruce forest & $\begin{array}{l}\text { South-east } \\
\text { Germany }\end{array}$ & $\begin{array}{l}50^{\circ} 08^{\prime} \mathrm{N} \\
11^{\circ} 52^{\prime} \mathrm{E}\end{array}$ & No reduction in annual & 1160 & Summer & Redistributed & $\begin{array}{l}\text { Fine root biomass, production and necro- } \\
\text { mass higher in treatment }\end{array}$ & Gaul et al. (2008) \\
\hline Grassland & $\begin{array}{l}\text { England } \\
\text { grasslands }\end{array}$ & $\begin{array}{l}1^{\circ} 20^{\prime} \mathrm{W} \\
51^{\circ} 46^{\prime} \mathrm{N}\end{array}$ & $\begin{array}{l}-90 \% \text { summer }+20 \% \\
\text { summer }\end{array}$ & $\mathrm{n} / \mathrm{a}$ & $\begin{array}{l}\text { Summer } \\
\text { and winter }\end{array}$ & $\begin{array}{l}\text { Increased and } \\
\text { reduced }\end{array}$ & $\begin{array}{l}\text { Abundance deceased } \\
\text { Abundance increased } \\
\text { Winter no effect }\end{array}$ & Morecroft et al. (2004) \\
\hline Savanna & $\begin{array}{l}\text { Oak - } \\
\text { savanna }\end{array}$ & $\begin{array}{l}30^{\circ} 34^{\prime \prime} \mathrm{N} \\
96^{\circ} 21^{\prime \prime} \mathrm{W}\end{array}$ & $\begin{array}{l}-40 \% \text { summer } \\
+ \text { spring and autumn }\end{array}$ & 1018 & $\begin{array}{l}\text { Summer, } \\
\text { spring and } \\
\text { autumn }\end{array}$ & Redistributed & $\begin{array}{l}\text { Reduced relative growth rate and } A_{n} \text { of } \\
\text { trees grown with grasses }\end{array}$ & $\begin{array}{l}\text { Volder et al. (2010); } \\
\text { Volder et al. (2013) }\end{array}$ \\
\hline Tropical rainforest & $\begin{array}{l}\text { Floresta, } \\
\text { Amazon, } \\
\text { Brazil }\end{array}$ & $\begin{array}{l}2.897^{\circ} \mathrm{S} \\
54.95^{\circ} \mathrm{W}\end{array}$ & $50 \%$ & $\sim 2000$ & Wet season & Reduced & $\begin{array}{l}\text { Non-sig. reduction of } 12 \% \text { of fruit pro- } \\
\text { duction. }\end{array}$ & Brando et al. (2006) \\
\hline Tropical rainforest & $\begin{array}{l}\text { Floresta, } \\
\text { Amazon, } \\
\text { Brazil }\end{array}$ & $\begin{array}{l}2.897^{\circ} \mathrm{S} \\
54.95^{\circ} \mathrm{W}\end{array}$ & $\begin{array}{l}35-41 \% \text { from } 2000 \text { to } \\
2004\end{array}$ & $\sim 2000$ & Wet season & Reduced & $\begin{array}{l}\text { Decrease, } 12 \% \text { first year, } 62 \% \text { after for } \\
\text { ANPP }\end{array}$ & Brando et al. (2008) \\
\hline Tropical rainforest & $\begin{array}{l}\text { Floresta, } \\
\text { Amazon, } \\
\text { Brazil }\end{array}$ & $\begin{array}{l}2.89^{\circ} \mathrm{S} \\
54.95^{\circ} \mathrm{W}\end{array}$ & $34-40 \%$ & $\sim 2000$ & Wet season & Reduced & $22 \%$ decrease in ANPP & Nepstad et al. (2002) \\
\hline Tropical rainforest & $\begin{array}{l}\text { Floresta, } \\
\text { Amazon, } \\
\text { Brazil }\end{array}$ & $\begin{array}{l}2.89^{\circ} \mathrm{S} \\
54.95^{\circ} \mathrm{W}\end{array}$ & $34-40 \%$ & $\sim 2000$ & Wet season & Reduced & $\begin{array}{l}\text { Soil water modelled, water budget esti- } \\
\text { mated }\end{array}$ & Belk et al. (2008) \\
\hline Tropical rainforest & $\begin{array}{l}\text { Floresta, } \\
\text { Amazon, } \\
\text { Brazil }\end{array}$ & $\begin{array}{l}2.89^{\circ} \mathrm{S} \\
54.95^{\circ} \mathrm{W}\end{array}$ & $60 \%$ & $\sim 2000$ & Wet season & Reduced & $34 \%$ increase in mortality & Nepstad et al. (2007) \\
\hline
\end{tabular}

by adding fewer but larger precipitation events, while maintaining the same total volume of water added (Harper et al., 2005) (Table 2).

\subsection{Seasonal changes in precipitation}

Impacts of seasonal changes in precipitation have been reported in boreal forests (Gaul et al., 2008), arctic tundra (Schimel et al., 2004), tropical rainforests in the Amazon (Nepstad et al., 2002; Brando et al., 2006; Brando et al., 2008), oak savannas (Volder et al., 2010; Volder et al., 2013) and Mediterranean regions, such as Spain (Miranda et al., 2009b). Although grasslands, savannas and Mediterranean forests differ markedly in the timing of ambient precipitation and the length of the growing season, experiments suggest patterns can be found in responses to seasonal changes in precipitation, such as strong changes in water stress and productivity in warm or dry seasons and not in cool or wet seasons. Below, we briefly outline the major experiments in these systems.

\subsubsection{Seasonal changes in boreal, subalpine and cold desert regions}

Manipulation of precipitation in semi-arid regions using rainout shelters and snow fences has led to alterations in biomass (Chimner et al., 2010; Thomey et al., 2011), the amount and timing of nutrient cycling (Schimel et al., 2004), and mortality and community composition (Schwinning et al., 2005a, b). In the cold desert grasslands in the Colorado Plateau (USA), with an MAP of $218 \mathrm{~mm}$, plant-water relations and growth of all three measured species were more sensitive to an imposed drought in summer compared with an imposed winter drought (Schwinning et al., 2005a, b). Finally, the projected changed timing of snowfall, in combination with rising temperatures, may lead to altered snowmelt and modify 
Table 2. Responses of vegetation to extreme precipitation. Biome, site location, latitude and longitude, experimental reduction in precipitation, Mean Annual Precipitation (MAP), and description of whether experimental reduction was annual (across the entire year) or during one season, in addition to the measured response and source reference. LTER stands for "Long Term Ecological Research" site. Results represent a selection of studies and are not a comprehensive list. Abbreviations: ANPP $=$ Above-ground net primary productivity; $A_{n}=$ photosynthesis; $\psi_{\mathrm{m}}=$ midday leaf water potential $(\mathrm{kPa}) ; \psi_{\mathrm{pd}}=$ predawn leaf water potential; $g_{\mathrm{s}}=$ stomatal conductance.

\begin{tabular}{|c|c|c|c|c|c|c|c|c|}
\hline Biome & Site & $\begin{array}{l}\text { Latitude and } \\
\text { longitude }\end{array}$ & $\begin{array}{l}\% \text { reduction in } \\
\text { precip }\end{array}$ & $\begin{array}{l}\text { MAP } \\
(\mathrm{mm})\end{array}$ & $\begin{array}{l}\text { Seasonal } \\
\text { /annual reduction? }\end{array}$ & $\begin{array}{l}P \text { reduced or } \\
\text { redistributed }\end{array}$ & Growth response & Reference \\
\hline Grassland & SE Spain & $\begin{array}{l}36^{\circ} 49^{\prime} \mathrm{N} \\
2^{\circ} 15^{\prime} \mathrm{W}\end{array}$ & $\begin{array}{l}75 \%, 50 \% ; \text { and } \\
\text { altered timing }\end{array}$ & 200 & $\begin{array}{l}\text { Seasonal and } \\
\text { annual }\end{array}$ & $\begin{array}{l}\text { Reduced and } \\
\text { redistributed }\end{array}$ & $\begin{array}{l}50 \% \text { reduction reduced productivity, } \\
\text { plant cover and diversity }\end{array}$ & Miranda et al. (2009b) \\
\hline Semi-arid grassland & Colorado USA & $\begin{array}{l}40^{\circ} 49^{\prime} \mathrm{N} \\
104^{\circ} 46^{\prime} \mathrm{W}\end{array}$ & None & 321 & None & Redistributed & $\begin{array}{l}\text { Extreme plots: higher ANPP, } A_{n} \text { and less } \\
\text { water stress }\left(\psi_{\mathrm{m}}\right)\end{array}$ & $\begin{array}{l}\text { Heisler-White } \\
\text { et al. (2008) }\end{array}$ \\
\hline Semi-arid grassland & $\begin{array}{l}\text { LTER, Nunn, } \\
\text { Colorado USA }\end{array}$ & $\begin{array}{l}40^{\circ} 49^{\prime} \mathrm{N} \\
104^{\circ} 46^{\prime} \mathrm{W}\end{array}$ & None & 321 & None & Redistributed & $\begin{array}{l}\text { Higher mean soil water content and } \\
\text { higher ANPP }\end{array}$ & $\begin{array}{l}\text { Heisler-White } \\
\text { et al. (2009) }\end{array}$ \\
\hline Mixed grass prairie & Hays, Kansas, USA & $\begin{array}{l}38^{\circ} 53^{\prime} \mathrm{N} \\
99^{\circ} 23^{\prime} \mathrm{W}\end{array}$ & None & 576 & None & Redistributed & $\begin{array}{l}\text { Higher mean soil water content and } \\
\text { higher ANPP }\end{array}$ & $\begin{array}{l}\text { Heisler-White } \\
\text { et al. (2009) }\end{array}$ \\
\hline Tall grass prairie & $\begin{array}{l}\text { Konza Prairie LTER, } \\
\text { Kansas, USA }\end{array}$ & $\begin{array}{l}39^{\circ} 05^{\prime} \mathrm{N} \\
96^{\circ} 35^{\prime} \mathrm{W}\end{array}$ & None & 835 & None & Redistributed & $\begin{array}{l}\text { Lower mean soil water content and higher } \\
\text { ANPP }\end{array}$ & $\begin{array}{l}\text { Heisler-White } \\
\text { et al. (2009) }\end{array}$ \\
\hline Grassland & $\begin{array}{l}\text { Konza Prairie LTER, } \\
\text { Kansas, USA }\end{array}$ & $\begin{array}{l}39.1^{\circ} \mathrm{N} \\
96.9^{\circ} \mathrm{W}\end{array}$ & $47-119 \%$ & 835 & $\begin{array}{l}\text { Increases and } \\
\text { decreases in } \\
\text { timing, size }\end{array}$ & $\begin{array}{l}\text { Reduced and } \\
\text { redistributed }\end{array}$ & $\begin{array}{l}\text { Increases in event size lead to more } \\
\text { ANPP, respiration and } A_{n}\end{array}$ & Fay et al. (2008) \\
\hline Grassland & $\begin{array}{l}\text { Konza Prairie LTER, } \\
\text { Kansas, USA }\end{array}$ & $\begin{array}{l}39^{\circ} 05^{\prime} \mathrm{N} \\
96^{\circ} 35^{\prime} \mathrm{W}\end{array}$ & $\begin{array}{l}30 \% \text { reduction } \\
\text { and altered tim- } \\
\text { ing. }\end{array}$ & 835 & $\begin{array}{l}\text { Seasonal and } \\
\text { annual }\end{array}$ & $\begin{array}{l}\text { Reduced and } \\
\text { redistributed }\end{array}$ & $\begin{array}{l}\text { Decreased soil fluxes by } 13 \% \text { and plant } \\
\text { productivity by } 8 \%\end{array}$ & Harper et al. (2005) \\
\hline Grassland & $\begin{array}{l}\text { Konza Prairie LTER, } \\
\text { Kansas, USA }\end{array}$ & $\begin{array}{l}39^{\circ} 05^{\prime} \mathrm{N} \\
96^{\circ} 35^{\prime} \mathrm{W}\end{array}$ & $\begin{array}{l}30 \% \text { reduction } \\
\text { and altered tim- } \\
\text { ing }\end{array}$ & 835 & None & $\begin{array}{l}\text { Reduced and } \\
\text { redistributed }\end{array}$ & $\begin{array}{l}\text { Variation in soil moisture was amplified in } \\
\text { plant growth responses }\end{array}$ & Fay et al. (2011) \\
\hline
\end{tabular}

the seasonal availability of soil water (Lambert et al., 2010). Changed timing of snowmelt may mask the changed seasonal availability of soil water when examining precipitation seasonality alone. Therefore, further studies on the impacts of rising temperatures and snowmelt on plant processes are a key research need.

\subsubsection{Seasonal changes in grasslands}

Seasonal redistribution experiments in grasslands have led to changes in ANPP, with results indicating that the response of ANPP depends on which seasons receive additional water and which seasons receive less water. The seasonality of precipitation was altered in grasslands in Oregon, USA, over seven years, moving $80 \%$ of annual precipitation to winter or spring (Bates et al., 2006). When precipitation was moved to winter, SWC and biomass did not change. In contrast, when precipitation was moved to spring, productivity reduced. Further, many of the biomass reductions did not occur until the fourth year of treatment. Apparently in spring, increased evaporation offset the increased amount of water, such that SWC did not increase enough to stimulate growth (Bates et al., 2006). Similarly, in a limestone grassland in England, $20 \%$ increases in summer precipitation increased summer growth, whereas increased autumn and winter precipitation had no effect on growth (Morecroft et al., 2004). This may be because reductions in precipitation are only likely to influence plant processes if soil moisture is in fact limiting in that season. Note that increases in spring precipitation led to growth reductions in Oregon, whereas increases in summer precipitation in England led to increases in growth. This may be because potential evapotranspiration was higher than water addition due to the warmer air in Oregon, compared with England.
A study on semi-arid plant communities in Spain conducted glasshouse experiments, using drought and seasonal precipitation redistribution treatments. The altered seasonality treatment reduced both spring and autumn by $15 \%$ and increased winter precipitation by $30 \%$. Accentuated seasonality decreased mean individual ANPP by $30 \%$, and did not alter flowering phenology (Miranda et al., 2009a). The absence of a flowering response contrasts with the Mediterranean woodland, where changing seasonal precipitation resulted in differences in phenology (Misson et al., 2011). These contrasting results are likely to be a consequence of the different treatments applied, species measured or biomes of origin, and highlight the importance of comparing different biomes (Beier et al., 2012).

\subsubsection{Seasonal changes in Mediterranean forest}

In the Mediterranean Quercus ilex forest, Montpelier, France, phenological responses of trees to seasonal drought were tested using rainout shelters (Misson et al., 2011). Exclusion of $97 \%$ of autumn precipitation did not significantly alter leaf, flower or fruit development. However, exclusion of $87 \%$ of spring precipitation resulted in water stress during important phases of leaf and fruit development. Only half of the sampled trees in the spring treatment reached the stage of functionally mature leaves, with the others abandoning leaf development at earlier stages. Further, only one of six female trees reached complete fruit maturation, though male flowers were unaffected, likely due to the higher resource requirements for female flowers and earlier leaf development, before highest water stress, compared with male flowers (Misson et al., 2011). These results indicate that the quantity of spring precipitation is more important than total annual precipitation for this system, with significant implications for 
vegetation predicted to receive reductions in precipitation in spring, such as that of Spain, France and south-east Australia.

\subsubsection{Seasonal changes in savanna}

An oak savanna in the southern USA received six years of precipitation redistribution, with $40 \%$ of summer precipitation redistributed to spring and autumn, intensifying the summer drought (Volder et al., 2013). Soil water content declined, leading to reduced photosynthesis and relative growth rates under seasonally redistributed precipitation, and tiller reproduction in grasses was delayed. However, redistributed precipitation had no effect on mortality. Results suggest that species composition of these oak savannas will alter in a climate where precipitation shifts from summer to spring and autumn (Volder et al., 2010).

\subsection{Extreme precipitation}

A suite of precipitation manipulation experiments have been conducted within a mesic grassland at the Konza Prairie Biological Station (Kansas, USA) (Knapp et al., 2001; Fay et al., 2002; Harper et al., 2005; Fay et al., 2008; Heisler and Knapp, 2008). One redistribution experiment examined how variation in quantity, event size and interval between precipitation events influenced SWC, ANPP, respiration and photosynthesis of tallgrass prairie grasses and forbs (Fay et al., 2008). Increases in event size led to more ANPP, although a threshold was reached and the effect decreased as the interval between precipitation events increased (see Fig. $2 \mathrm{~g}$ in Fay et al., 2008). It is clear that increasing water did not always lead to increased ANPP, with a threshold of maximum SWC at $600 \mathrm{~mm}$ MAP in Fay et al. (2008). Another study at Konza Prairie Biological Station imposed extreme precipitation over four growing seasons (Harper et al., 2005). A $50 \%$ increase in the length of dry intervals while holding the total volume constant led to $19 \%$ reductions in soil water content, and $9 \%$ reductions in ANPP (Harper et al., 2005). Soil type played a role in the response of plant processes, with soil that is able to retain water having a more muted effect than sandy soils which lose water to deep drainage.

A comprehensive set of extreme precipitation experiments measured ANPP across a precipitation gradient in southern USA grasslands. Precipitation was applied as either 12,6 or 4 events, with the same total amount of water applied (HeislerWhite et al., 2008). The responses from this xeric, semiarid steppe were compared with a mixed-grass prairie and a mesic tallgrass prairie along a $600 \mathrm{~km}$ productivity and precipitation gradient (Heisler-White et al., 2009). Responses of ANPP depended on mean soil water content, and an aridity index (MAP/potential evapotranspiration) for each grassland type. Soil water content was influenced by soil type, with a higher clay content at the mesic site than the two xeric sites (Heisler-White et al., 2009). At the two more xeric (waterlimited, aridity index $<1$, see Table 3 ) sites, extreme precip- itation caused more time at above-average SWC, increasing ANPP. In contrast, at the more mesic (water-abundant, aridity index $>1$ ) site, extreme precipitation led to extended periods of below-average SWC, reducing ANPP (Heisler-White et al., 2009). This comparison suggests there was a threshold of plant-available water to extreme precipitation across these studies and that initial site conditions such as the aridity index, soil type and rooting depth will influence growth responses to altered timing of precipitation.

\subsection{Modelling studies}

Modelling studies on altered precipitation enable comparisons across ecosystems. Modelling studies generally suggest that shifts in the timing of precipitation alter both plant community composition and Net Primary Productivity, (NPP) (Epstein et al., 1999; Gerten et al., 2008). A study examining the impact of changed seasonality in precipitation using the dynamic global vegetation model LPJ reported that deciduous and semi-deciduous forests in Africa were more sensitive than other plant functional types to changes in the seasonality of precipitation (Hely et al., 2006). Dry sites and periods generally are more affected by shifts in precipitation compared with wet sites and periods (Gerten et al., 2008), as has been found in some empirical studies (Knapp et al., 2002). Similarly, shifts in seasonality that alter the amount of precipitation during the spring may have larger effects on community composition and NPP than shifts in seasonality during other seasons (Wiles et al., 2011). More generally, shifts in precipitation likely will affect NPP in water-limited systems because of the close link between NPP and precipitation in these systems (Gerten et al., 2008). However, the effect of shifts in precipitation may reflect the length of the dry period (Gerten et al., 2008) and interactions with other climate change variables, including $\mathrm{CO}_{2}$ and temperature (Luo et al., 2008).

\section{Synthesis}

\subsection{Synthesis on seasonal changes}

Redistributing the seasonality of precipitation not only influences water stress and biomass, but phenological changes such as flowering of male and female plants (Misson et al., 2011) and tiller production (Volder et al., 2013). Redistributed precipitation resulting in reductions in spring or summer precipitation often led to water stress and was associated with reduced biomass and altered phenology, while the subsequent increases in autumn or winter precipitation had little or no effect on plant processes. Similarly, increased summer precipitation had a larger effect on SWC and biomass than winter increases. In summary, changed precipitation in spring and summer had a more dramatic impact on vegetation than changes in autumn and winter, reflecting larger effects of redistributed rainfall on SWC during warm 
Table 3. Synthesis of extreme precipitation studies on the soil water content (SWC) and above-ground net primary productivity (ANPP), mean annual precipitation (MAP) and mean annual potential evapotranspiration $\left(E_{\text {pot }}\right)$ of grasslands, showing that ANPP either increases or decreases in the same direction as SWC. CO stands for Colorado, KS stands for Kansas. Ecosystem is defined using the Köppen climate definition (McKnight and Hess, 2000).

\begin{tabular}{|c|c|c|c|c|c|c|}
\hline Ecosystem and Köppen climate definition & SWC & ANPP & MAP $(\mathrm{mm})$ & $E_{\text {pot }}(\mathrm{mm})$ & $\begin{array}{l}\text { Aridity index } \\
\left.\text { (MAP/ } E_{\text {pot }}\right)\end{array}$ & Reference \\
\hline Shortgrass prairie: semi-arid & $\uparrow 15 \%$ & $\uparrow 77 \%$ & $321, \mathrm{CO}$ & $>1000$ & $<0.32$ & Heisler-White et al. (2008) \\
\hline Shortgrass prairie: semi-arid & $\uparrow 19 \%$ & $\uparrow 30 \%$ & $321, \mathrm{CO}$ & $>1000$ & $<0.32$ & Heisler-White et al. (2009) \\
\hline $\begin{array}{l}\text { Mixed grass prairie: } \\
\text { ecotone between semi-arid and humid subtropical }\end{array}$ & Increase & $\uparrow 70 \%$ & $576, \mathrm{KS}$ & 749 & 0.77 & Heisler-White et al. (2009) \\
\hline Tallgrass prairie: humid subtropical & $\downarrow 19 \%$ & $\downarrow 9 \%$ & $835, \mathrm{KS}$ & 687 & 1.21 & Harper et al. (2005) \\
\hline Tallgrass prairie: humid subtropical & $\downarrow 20 \%$ & $\downarrow 18 \%$ & $835, \mathrm{KS}$ & 687 & 1.21 & Heisler-White et al. (2009) \\
\hline Tallgrass prairie: humid subtropical & $\downarrow 14 \%$ & $\downarrow 15 \%$ & $835, \mathrm{KS}$ & 687 & 1.21 & Fay et al. (2011) \\
\hline
\end{tabular}

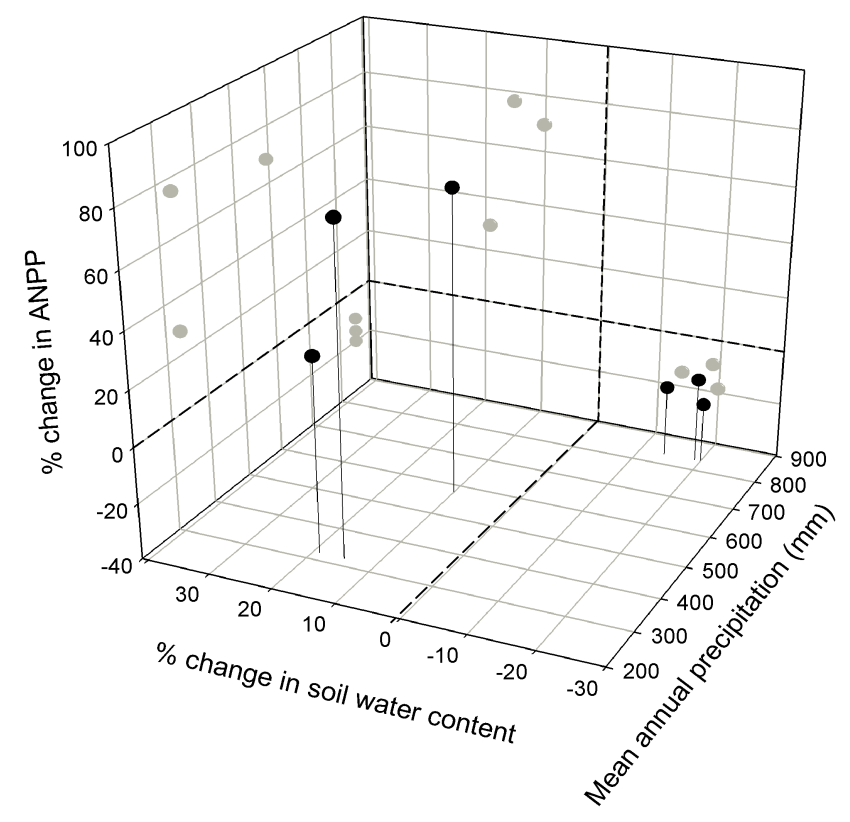

Figure 2. The effect of extreme precipitation on above-ground net primary productivity (ANPP) across a rainfall gradient. The threedimensional plot shows the relationship between relative changes in soil water content (\%) and the percent change in above-ground net primary productivity ANPP (\%) due to extreme precipitation, based on the mean annual precipitation $(\mathrm{mm})$ of the site. The site aridity index for each site is presented in Table 3. The black dots represent data points on the $x, y$ and $z$ axes. The grey dots represent where the data would fall in a two-dimensional scatter plot. Dashed lines represent the zero line, where $\%$ change in soil water content or ANPP is zero.

or dry months compared with cool or wet months. It is noteworthy that the majority of studies that altered seasonal precipitation were conducted in grasslands, with few studies on trees.

\subsection{Synthesis on extreme precipitation}

The response to extreme precipitation differed in xeric (water-limited) and comparatively mesic (water-abundant) sites. Studies to date suggest that xeric ecosystems generally were associated with positive responses of ANPP to extreme precipitation, while comparatively mesic ecosystems were associated with negative responses of ANPP. This pattern was supported by rainout shelter, observational and modelling studies. In general, within ecosystems which were not water-limited ( $>600 \mathrm{~mm}$ MAP, or an aridity index $>1.0$ ) (Harper et al., 2005; Fay et al., 2011) extreme precipitation led to a reduction in mean soil water content, followed by a reduction in growth or ANPP (Fig. 2). In contrast, below $600 \mathrm{~mm}$ or an aridity index of $<1$, soil water content and ANPP increased. A landscape-scale study used remote sensing to quantify a threshold on plant responses to drought in the south-west USA (Clifford et al., 2013; Hicke and Zeppel, 2013). Clifford et al. (2013) observed high die-off and mortality rates at sites below $600 \mathrm{MAP}$, whereas there were no observations of mortality above the threshold, presumably due to an absence of water limitation. Finally, many ecosystems convert from grassland/savanna to denser forests as MAP increases above potential evapotranspiration, when the aridity index exceeds 1 , meaning the effects of extreme precipitation may also coincide with changes in ecosystem type.

It is crucial to note, however, that soil characteristics such as soil type (clay, loam or sand), soil depth and rooting depth influence plant-available water, regardless of MAP, and further studies are required to test plant responses to extreme precipitation across other soil types, plant functional types and biomes. Little research has been conducted in tropical, tundra and boreal regions on plant responses to altered timing of precipitation. Of the studies from boreal regions to date, only one described the impact of altered precipitation on roots, but not on above-ground processes (Gaul et al., 2008). These temperature-limited systems may show markedly different responses compared to warmer biomes. Further, the seasons that precipitation is shifted from and to will play a role. For example, reductions in spring precipitation may not be detrimental to ANPP unless soil moisture is limiting in that season. Similarly, sites with higher MAP may respond significantly differently if precipitation were 


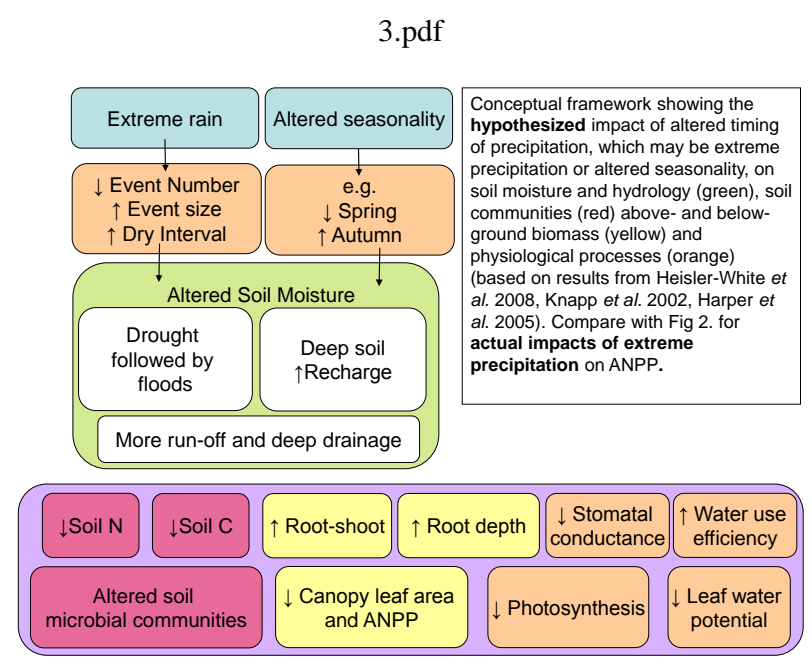

Figure 3. Conceptual framework showing the possible impacts of extreme and seasonal precipitation on soil and plant processes. Based upon Heisler-White et al., 2008; Knapp et al., 2002, and Harper et al., 2005. The bottom panel, purple, shows plant and soil responses when the overall response to extreme precipitation is a decrease in soil water content. Arrow directions will be reversed when the overall response to extreme precipitation is an increase in soil water.

concentrated within the growing season or, instead, during the winter months. We may also expect different responses from shallow- and deep-rooted plants, such as juvenile versus mature plants. If rain falls in large volumes in short periods, the water may drain away before shallow-rooted plants are able to use it (Fig. 3). However, deep-rooted plants are likely to access deeper stores of water and show more dampened responses than grasses. Alternatively, decreased water availability resulting from extreme precipitation may lead to increased root depth and volume. However, recent studies report that deep-rooted plants do not always tolerate drought stress better than shallow-rooted plants, indicating further research is required to elucidate the mechanisms explaining these unexpected differences across rooting depths (Morecroft et al., 2004; West et al., 2012).

\section{Key research gaps and unresolved problems}

This review indicates key research gaps in understanding the effects of extreme and seasonal changes in precipitation. These include (1) responses of a broad range of plant functional types, particularly trees, (2) responses of boreal and temperate forests, (3) effects on below ground processes, and (4) the effects of changes in precipitation in conjunction with heat waves, rising temperatures and increasing $\left[\mathrm{CO}_{2}\right]$. Most research in this field has examined the influence of extreme or seasonal changes in precipitation on grasslands (Knapp et al., 2008; Heisler-White et al., 2009; Fay et al., 2011), with few studies on tree species (Zeppel, 2013). Further, there is a paucity of studies describing the effects of altered precipitation on biomes such as tundra, boreal forests and temperate forests. Our current understanding of below-ground processes and how these respond to extreme precipitation is lacking, particularly in forests and woodlands, in part due to logistical constraints. Finally, very few studies exist describing plant responses to interactions between altered precipitation and heat waves, and none, to our knowledge, with altered precipitation and elevated $\left[\mathrm{CO}_{2}\right]$. To address these knowledge gaps, future work is needed, testing whether

1. tree responses to seasonal changes in precipitation are buffered compared to grasses;

2. seedlings and shallow-rooted plants show different responses to altered precipitation than mature or deeprooted plants, and what causes these differences;

3. heat waves exacerbate the water stress from extreme precipitation in xeric regions and ameliorate water logging in mesic regions.

\section{Conclusions}

Extreme precipitation, by definition, leads to wetter (waterlogged) and drier conditions, and it is clear that the influence of extreme precipitation on plant growth is not consistent across ecosystems. Rather, the available data generally suggest biomass either decreased or increased depending on whether the average soil water content decreased or increased respectively. In turn, the change in soil water content depended on the aridity index and soil type. The response of ANPP to extreme precipitation in grasslands was an increase in water-limited sites, associated with increased SWC. In contrast, extreme precipitation led to a decrease in soil water content and ANPP in mesic sites. Data are needed across a range of root depths, soil types, plant ages, plant functional types and patterns of seasonal redistribution of precipitation to refine and assess the broad applicability of this pattern.

Seasonal changes in precipitation often led to significant water stress, changes in phenology and decreased biomass, but the effect depended on the direction of the change in precipitation and differed among seasons. Reductions in spring or summer often led to water stress, altered phenology, including reduced fruit and leaf development, as well as reduced biomass, with subsequent reductions in autumn or winter having no effect. Similarly, increased summer precipitation had a larger positive impact on biomass than winter increases. In summary, across forests and grasslands changed precipitation in summer and spring had a larger impact on vegetation than changes in winter and autumn. Thus, in conclusion, studies showed a clear pattern exists, as described in Table 3. The initial conditions, and whether the site is water limited or water abundant, are key factors driving water 
relations and productivity under extreme precipitation. Similarly, even when total precipitation remains unchanged, seasonal shifts may alter water relations and productivity as well as phenology, leaf and fruit development, with more marked changes in summer and spring compared with winter and autumn. Considering projections of seasonal redistribution of precipitation, these patterns across studies suggest we can expect key biological changes including increased water stress and changes in biomass, wood, leaf and fruit development.

This improved understanding of plant and ecosystem responses to extreme precipitation and seasonal changes in precipitation will inform emerging vegetation models and enable better understanding of vegetation, carbon and water resources in future climates.

Acknowledgements. The authors thank Kate Holland for useful suggestions on an earlier draft, and Phillip Fay, Alan Knapp, Michelle Leishman and David Tissue for useful discussions. M. J. B. Zeppel was supported by a Macquarie University Research Fellowship and an ARC Discovery Early Career Researcher Fellowship, and J. D. Lewis by a fellowship from Fordham University.

Edited by: P. Stoy

\section{References}

Adams, H. D., Luce, C. H., Breshears, D. D., Allen, C. D., Weiler, M., Hale, V. C., Smith, A. M. S., and Huxman, T. E.: Ecohydrological consequences of drought- and infestation-triggered tree die-off: insights and hypotheses, Ecohydrology, 5, 145-159, 2011.

Allen, C. D., Macalady, A. K., Chenchouni, H., Bachelet, D., McDowell, N., Vennetier, M., Kitzberger, T., Rigling, A., Breshears, D. D., Hogg, E. H., Gonzalez, P., Fensham, R., Zhang, Z., Castro, J., Demidova, N., Lim, J. H., Allard, G., Running, S. W., Semerci, A., and Cobb, N.: A global overview of drought and heat-induced tree mortality reveals emerging climate change risks for forests, Forest Ecol. Manag., 259, 660-684, 2010.

Anderegg, W. R. L., Plavcová, L., Anderegg, L. D. L., Hacke, U. G., Berry, J. A., and Field, C. B.: Drought's legacy: multiyear hydraulic deterioration underlies widespread aspen forest dieoff and portends increased future risk, Global Change Biol., 19, 1188-1196, 2013.

Bates, J. D., Svejcar, T., Miller, R. F., and Angell, R. A.: The effects of precipitation timing on sagebrush steppe vegetation, J. Arid Environ., 64, 670-697, 2006.

Beier, C., Beierkuhnlein, C., Wohlgemuth, T., Penuelas, J., Emmett, B., Korner, C., De Boeck, H. J., Christensen, J. H., Leuzinger, S., and Janssens, I. A.: Precipitation manipulation experiments - challenges and recommendations for the future, Ecol. Lett., 15, 899-911, 2012.

Belk, E. L., Markewitz, D., Rasmussen, T. C., Carvalho, E. J. M., Nepstad, D. C., and Davidson, E. A.: Modeling the effects of throughfall reduction on soil water content in a Brazilian Oxisol under a moist tropical forest, Water Resour. Res., 44, W08432, doi:10.1029/2006WR005493, 2008 .
Bonan, G. B.: Ecological climatology., Second Edition edn, Cambridge University Press, Cambridge, U. K., 2008.

Brando, P., Ray, D., Nepstad, D., Cardinot, G., Curran, L. M., and Oliveira, R.: Effects of partial throughfall exclusion on the phenology of Coussarea racemosa (Rubiaceae) in an east-central Amazon rainforest, Oecologia, 150, 181-189, 2006.

Brando, P. M., Nepstad, D. C., Davidson, E. A., Trumbore, S. E., Ray, D., and Camargo, P.: Drought effects on litterfall, wood production and below-ground carbon cycling in an Amazon forest: results of a throughfall reduction experiment, Philos. T. R. Soc. B, 363, 1839-1848, 2008.

Breshears, D. D., Myers, O. B., Meyer, C. W., Barnes, F. J., Zou, C. B., Allen, C. D., McDowell, N. G., and Pockman, W. T.: Tree die-off in response to global change-type drought: mortality insights from a decade of plant water potential measurements, Front. Ecol. Environ., 7, 185-189, 2009.

Brzostek, E. R., Blair, J. M., Dukes, J. S., Frey, S. D., Hobbie, S. E., Melillo, J. M., Mitchell, R. J., Pendall, E., Reich, P. B., Shaver, G. R., Stefanski, A., Tjoelker, M. G., and Finzi, A. C.: The effect of experimental warming and precipitation change on proteolytic enzyme activity: positive feedbacks to nitrogen availability are not universal, Glob. Change Biol., 18, 2617-2625, 2012.

Chimner, R. A., Welker, J. M., Morgan, J., LeCain, D., and Reeder, J.: Experimental manipulations of winter snow and summer rain influence ecosystem carbon cycling in a mixed-grass prairie, Wyoming, USA, Ecohydrology, 3, 284-293, 2010.

Christensen, J. H., Hewitson, B., Busuioc, A., Chen, A., Gao, X., Held, R., Jones, R., Kolli, R. K., Kwon, W.-T., Laprise, V., Magana Rueda, L., Mearns, G. G., Menendez, C. G., Rainsanen, J., Rinke, A., Sarr, A., and Whetton, P.: Regional Climate Projections. Climate Change 2007: The Physical Science Basis. Contribution of Working Group I to the Fourth Assessment Report of the Intergovernmental Panel on Climate Change, edited by: Solomon, S., Qin, D., Manning, M., Chen, Z., Marquis, M., Averyt, K. B., Tignor, M., and Miller, H. L., Cambridge University Press, Cambridge, UK and New York, NY, USA, 2007.

Clifford, M. J., Royer, P. D., Cobb, N. S., Breshears, D. D., and Ford, P. L.: Precipitation thresholds and drought-induced tree die-off: insights from patterns of Pinus edulis mortality along an environmental stress gradient, New Phytol., 200, 413-421, doi:10.1111/nph.12362, 2013.

CSIRO: Climate change: science and solutions for Australia, edited by: Cleugh, H., Stafford Smith, M., Battaglia, M., and Graham, P., CSIRO Publishing, Collingwood, Victoria, 2011.

Dreesen, F. E., De Boeck, H. J., Janssens, I. A., and Nijs, I.: Do successive climate extremes weaken the resistance of plant communities? An experimental study using plant assemblages, Biogeosciences, 11, 109-121, doi:10.5194/bg-11-109-2014, 2014.

Epstein, H. E., Burke, I. C., and Lauenroth, W. K.: Response of the shortgrass steppe to changes in rainfall seasonality, Ecosystems, 2, 139-150, 1999.

Fay, P. A., Carlisle, J. D., Danner, B. T., Lett, M. S., McCarron, J. K., Stewart, C., Knapp, A. K., Blair, J. M., and Collins, S. L.: Altered rainfall patterns, gas exchange, and growth in grasses and forbs, Int. J. Plant Sci., 163, 549-557, 2002.

Fay, P. A., Kaufman, D. M., Nippert, J. B., Carlisle, J. D., and Harper, C. W.: Changes in grassland ecosystem function due 
to extreme rainfall events: implications for responses to climate change, Glob. Change Biol., 14, 1600-1608, 2008.

Fay, P. A., Blair, J. M., Smith, M. D., Nippert, J. B., Carlisle, J. D., and Knapp, A. K.: Relative effects of precipitation variability and warming on tallgrass prairie ecosystem function, Biogeosciences, 8, 3053-3068, doi:10.5194/bg-8-3053-2011, 2011.

Fravolini, A., Hultine, K. R., Brugnoli, E., Gazal, R., English, N. B., and Williams, D. G.: Precipitation pulse use by an invasive woody legume: the role of soil texture and pulse size, Oecologia, 144, 618-627, 2005.

Gaul, D., Hertel, D., Borken, W., Matzner, E., and Leuschner, C.: Effects of experimental drought on the fine root system of mature Norway spruce, Forest Ecol. Manag., 256, 1151-1159, 2008.

Gerten, D., Luo, Y., Le Maire, G., Parton, W. J., Keough, C., Weng, E., Beier, C., Ciais, P., Cramer, W., Dukes, J. S., Hanson, P. J., Knapp, A. A. K., Linder, S., Nepstad, D., Rustad, L., and Sowerby, A.: Modelled effects of precipitation on ecosystem carbon and water dynamics in different climatic zones, Glob. Change Biol., 14, 2365-2379, 2008.

Hanson, P. J., Huston, M. A., and Todd, D. E.: Walker branch throughfall displacement experiment, North American temperate deciduous forest resonses to changing precipitation regimes, Springer-Verlag, New York., 2003.

Harper, C. W., Blair, J. M., Fay, P. A., Knapp, A. K., and Carlisle, J. D.: Increased rainfall variability and reduced rainfall amount decreases soil $\mathrm{CO}_{2}$ flux in a grassland ecosystem, Glob. Change Biol., 11, 322-334, 2005.

Heisler, J. L. and Knapp, A. K.: Temporal coherence of aboveground net primary productivity in mesic grasslands, Ecography, 31, 408-416, 2008.

Heisler-White, J. L., Knapp, A. K., and Kelly, E. F.: Increasing precipitation event size increases above-ground net primary productivity in a semi-arid grassland, Oecologia, 158, 129-140, 2008.

Heisler-White, J. L., Blair, J. M., Kelly, E. F., Harmoney, K., and Knapp, A. K.: Contingent productivity responses to more extreme rainfall regimes across a grassland biome, Glob. Change Biol., 15, 2894-2904, 2009.

Hely, C., Bremond, L., Alleaume, S., Smith, B., Sykes, M. T., and Guiot, J.: Sensitivity of African biomes to changes in the precipitation regime, Global. Ecol. Biogeogr., 15, 258-270, 2006.

Hicke, J. and Zeppel, M. J. B.: Climatic thresholds to droughtinduced die-off: Precipitation and VPD thresholds for Pinus edulis along a multi-site gradient, New Phytol., 200, 301-303, 2013.

Huntington, T. G.: Evidence for intensification of the global water cycle: review and synthesis, J. Hydrol., 319, 83-95, 2006.

Huxman, T. E., Smith, M. D., Fay, P. A., Knapp, A. K., Shaw, M. R., Lolk, M. E., Smith, S. D., Tissue, D. T., Zak, J. C., Weltzin, J. F., Pockman, W. T., Sala, O. E., Haddad, B. M., Harte, J., Koch, G. W., Schwinning, S., Small, E. E., and Williams, D. G.: Convergence across biomes to a common rain-use efficiency, Nature, 429, 651-654, 2004.

IPCC: Summary for Policymakers, in: Intergovernmental Panel on Climate Change Special Report on Managing the Risks of Extreme Events and Disasters to Advance Climate Change Adaptation, edited by: Field, C. B., Barros, V., Stocker, T. F., Qin, D., Dokken, D., Ebi, K. L., Mastrandrea, M. D., Mach, K. J., Plattner, G.-K., Allen, S. K., Tignor M., and Midgley, P. D., Cam- bridge University Press, Cambridge, UK and New York, NY, USA, 2011.

Keith, H., Mackey, B. G., and Lindenmayer, D. B.: Re-evaluation of forest biomass carbon stocks and lessons from the world's most carbon-dense forests, P. Natl. Acad. Sci. USA, 106, 1163511640,2009

Knapp, A. K., Briggs, J. M., and Koelliker, J. K.: Frequency and extent of water limitation to primary production in a mesic temperate grassland, Ecosystems, 4, 19-28, 2001.

Knapp, A. K., Fay, P. A., Blair, J. M., Collins, S. L., Smith, M. D., Carlisle, J. D., Harper, C. W., Danner, B. T., Lett, M. S., and McCarron, J. K.: Rainfall variability, carbon cycling, and plant species diversity in a mesic grassland, Science, 298, 2202-2205, 2002.

Knapp, A. K., Beier, C., Briske, D. D., Classen, A. T., Yiqi, L., Reichstein, M., Smith, M. D., Smith, S. D., Bell, J. E., Fay, P. A., Heisler, J. L., Leavitt, S. W., Sherry, R., Smith, B., and Weng, E.: Consequences of more extreme precipitation regimes for terrestrial ecosystems, Bioscience, 58, 811-821, 2008.

Lambert, A. M., Miller-Rushing, A. J. \& Inouye, D.W. (2010) Changes in snowmelt date and summer precipitation affect the flowering phenology of Erythronium grandiflorum (glacier lily; Liliaceae). American Journal of Botany, 97, 1431-1437.

Luo, Y. Q., Gerten, D., Le Maire, G., Parton, W. J., Weng, E. S., Zhou, X. H., Keough, C., Beier, C., Ciais, P., Cramer, W. Dukes, J. S., Emmett, B., Hanson, P. J., Knapp, A., Linder, S., Nepstad, D., and Rustad, L.: Modeled interactive effects of precipitation, temperature, and $\left[\mathrm{CO}_{2}\right]$ on ecosystem carbon and water dynamics in different climatic zones, Glob. Change Biol., 14, 1986-1999, 2008.

Luo, Y., Melillo, J., Niu, S., Beier, C., Clark, J. S., Classen, A. T., Davidson, E., Dukes, J. S., Evans, R. D., Field, C. B., Czimczik, C. I., Keller, M., Kimball, B. A., Kueppers, L. M., Norby, R. J., Pelini, S. L., Pendall, E., Rastetter, E., Six, J., Smith, M., Tjoelker, M. G., and Torn, M. S.: Coordinated approaches to quantify long-term ecosystem dynamics in response to global change, Glob. Change Biol., 17, 843-854, 2011.

McKnight, T. and Hess, D.: Climate Zones and Types. Physical Geography: A Landscape Appreciation, Prentice-Hall, Upper Saddle River, NJ, 2000.

Miranda, J. D., Padilla, F. M., and Pugnaire, F. I.: Response of a Mediterranean semi-arid community to changing patterns of water supply, Persp. Plant Ecol. Evol. Syst., 11, 255-266, 2009a.

Miranda, J. D., Padilla, F. M., Lazaro, R., and Pugnaire, F. I.: Do changes in rainfall patterns affect semi-arid annual plant communities?, J. Vegetat. Sci., 20, 269-276, 2009b.

Misson, L., Degueldre, D., Collin, C., Rodriguez, R., Rocheteau, A., Ourcival, J. M., and Rambal, S.: Phenological responses to extreme droughts in a Mediterranean forest, Glob. Change Biol., 17, 1036-1048, 2011.

Morecroft, M.D., Masters, G.J., Brown, V.K., Clarke, I.P., Taylor, M.E. \& Whitehouse, A.T. (2004) Changing precipitation patterns alter plant community dynamics and succession in an ex-arable grassland. Functional Ecology, 18, 648-655.

Morecroft, M. D., Masters, G. J., Brown, V. K., Clarke, I. P., Taylor, M. E., and Whitehouse, A. T.: Changing precipitation patterns alter plant community dynamics and succession in an exarable grassland, Funct. Ecol., 18, 648-655, 2004. 
Nepstad, D. C., Moutinho, P., Dias, M. B., Davidson, E., Cardinot, G., Markewitz, D., Figueiredo, R., Vianna, N., Chambers, J., Ray, D., Guerreiros, J. B., Lefebvre, P., Sternberg, L., Moreira, M., Barros, L., Ishida, F. Y., Tohlver, I., Belk, E., Kalif, K., and Schwalbe, K.: The effects of partial throughfall exclusion on canopy processes, above-ground production, and biogeochemistry of an Amazon forest, J. Geophys. Res.-Atmos., 107, 8085, doi:10.1029/2001JD000360, 2002.

Pitman, A. J. and Perkins, S. E.: Regional projections of future seasonal and annual changes in rainfall and temperature over Australia based on skill-selected AR(4) models, Earth Interact., 12, 1-50, doi:10.1175/2008EI260.1, 2008.

Potts, D. L., Huxman, T. E., Enquist, B. J., Weltzin, J. F., and Williams, D. G.: Resilience and resistance of ecosystem functional response to a precipitation pulse in a semi-arid grassland, J. Ecol., 94, 23-30, 2006.

Resco, V., Ewers, B. E., Sun, W., Huxman, T. E., Weltzin, J. F., and Williams, D. G.: Drought-induced hydraulic limitations constrain leaf gas exchange recovery after precipitation pulses in the C(3) woody legume, Prosopis velutina, New Phytol., 181, 672682, 2009.

Reyer, C., Leuzinger, S., Rammig, A., Wolf, A., Bartholomeus, R. P., Bonfante, A., de Lorenzi, F., Dury, M., Gloning, P., Abou Jaoudé, R., Klein, T., Kuster, T. M., Martins, M., Niedrist, G., Riccardi, M., Wohlfahrt, G., de Angelis, P., de Dato, G., François, L., Menzel, A., and Pereira, M.: A plant's perspective of extremes: terrestrial plant responses to changing climatic variability, Glob. Change Biol., 19, 75-89, doi:10.1111/gcb.12023, 2012.

Schimel, J. P., Bilbrough, C., and Welker, J. A.: Increased snow depth affects microbial activity and nitrogen mineralization in two Arctic tundra communities, Soil Biol. Biochem., 36, $217-$ 227, 2004

Schwinning, S. and Sala, O. E.: Hierarchy of responses to resource pulses in and and semi-arid ecosystems, Oecologia, 141, 211220, 2004

Schwinning, S., Starr, B. I., and Ehleringer, J. R.: Summer and winter drought in a cold desert ecosystem (Colorado Plateau), Part II: Effects on plant carbon assimilation and growth, J. Arid Environ., 61, 61-78, 2005a.

Schwinning, S., Starr, B. I., and Ehleringer, J. R.: Summer and winter drought in a cold desert ecosystem (Colorado Plateau), Part I: Effects on soil water and plant water uptake, J. Arid Environ., 60, 547-566, 2005b.

Smith, M. D.: An ecological perspective on extreme climatic events: a synthetic definition and framework to guide future research, J. Ecol., 99, 656-663, 2011.

Thomey, M. L., Collins, S. L., Vargas, R., Johnson, J. E., Brown, R. F., Natvig, D. O., and Friggens, M. T.: Effect of precipitation variability on net primary production and soil respiration in a Chihuahuan Desert grassland, Glob. Change Biol., 17, 1505-1515, 2011.
Thompson, R. M., Beardall, J., Beringer, J., Grace, M., and Sardina, P.: Means and extremes: building variability into community-level climate change experiments, Ecol. Lett., 16, 799-806, 2013

Volder, A., Tjoelker, M. G., and Briske, D. D.: Contrasting physiological responsiveness of establishing trees and a C(4) grass to rainfall events, intensified summer drought, and warming in oak savanna, Glob. Change Biol., 16, 3349-3362, 2010.

Volder, A., Briske, D. D., and Tjoelker, M. G.: Climate warming and precipitation redistribution modify tree-grass interactions and tree species establishment in a warm-temperate savanna, Glob. Change Biol., 19, 843-857, 2013.

Weltzin, J. F., Loik, M. E., Schwinning, S., Williams, D. G., Fay, P. A., Haddad, B. M., Harte, J., Huxman, T. E., Knapp, A. K., Lin, G. H., Pockman, W. T., Shaw, M. R., Small, E. E., Smith, M. D., Smith, S. D., Tissue, D. T., and Zak, J. C.: Assessing the response of terrestrial ecosystems to potential changes in precipitation, Bioscience, 53, 941-952, 2003.

West, A. G., Dawson, T. E., February, E. C., Midgley, G. F., Bond, W. J., and Aston, T. L.: Diverse functional responses to drought in a Mediterranean-type shrubland in South Africa, New Phytol., 195, 396-407, 2012.

Wiles, L. J., Dunn, G., Printz, J., Patton, B., and Nyren, A.: Spring Precipitation as a Predictor for Peak Standing Crop of MixedGrass Prairie, Rangeland Ecol. Manage., 64, 215-222, 2011.

Wullschleger, S. D. and Hanson, P. J.: Sensitivity of canopy transpiration to altered precipitation in an upland oak forest: evidence from a long-term field manipulation study, Glob. Change Biol., 12, 97-109, 2006.

Zeppel, M. J. B.: Convergence of tree water use and hydraulic architecture in water-limited regions: a review and synthesis, Ecohydrology, 6, 889-900, doi:10.1002/eco.1377, 2013.

Zeppel, M. J. B., Adams, H. D., and Anderegg, W. R. L.: Mechanistic causes of tree drought mortality: recent results, unresolved questions and future research needs, New Phytol., 192, 800-803, 2011.

Zeppel, M. J. B., Macinnis-Ng, C. M. O., Ford, C. R., and Eamus, D.: The response of sap flow to pulses of rain in a temperate Australian woodland, Plant Soil, 305, 121-130, 2008a.

Zeppel, M. J. B., Macinnis-Ng, C. M. O., Yunusa, I. A. M., Whitley, R. J., and Eamus, D.: Long term trends of stand transpiration in a remnant forest during wet and dry years, J. Hydrol., 349, 200-213, 2008b.

Zhang, Y., Susan Moran, M., Nearing, M. A., Ponce Campos, G. E., Huete, A. R., Buda, A. R., Bosch, D. D., Gunter, S. A., Kitchen, S. G., Henry McNab, W., Morgan, J. A., McClaran, M. P., Montoya, D. S., Peters, D. P. C., and Starks, P. J.: Extreme precipitation patterns and reductions of terrestrial ecosystem production across biomes, J. Geophys. Res., 118, 148-157, 2013. 